\title{
GEORGE BENTHAM, F.R.S.
}

\author{
(With Portrait.)
}

THE following account of the life and labours of George Bentham is based on an obituary notice which I communicated to Nature (Vol. XXX, October I884, p. 359). In reproducing it in the present form, I have enlarged it considerably, and further availed myself of four subsequent accounts, namely, of Mr. Thiselton-Dyer's Eulogium, read before the Linnean Society (Proceedings, Sessions 1887-1889); of Prof. Gray's Memorial, presented to the American Academy of Arts and Sciences (Journal, Vol. XXIX, February, I 885); of Prof. Oliver's Obituary notice (Proc. Royal Society, I885), and of Mr. Daydon Jackson's notice (Proc. Linn. Soc., Session I884-5). The reminiscences of his very early life are taken from an autobiography which he commenced very shortly before his death, but which he was unable to continue.

The life of George Bentham presents such variety, such startling changes of conditions, and a combination of so many natural and acquired mental powers of a high order, that it cannot be perused without the question arising, how far heredity and environments had influenced his career. Such being the case, I think no apology is needed for commencing this sketch with some account of his parentage.

He was born on September 22, 1800 , in the village of Stoke, near Portsmouth. His father, afterwards Sir Samuel Bentham, who was the son of a wealthy scrivener in the Minories, and the only brother of Jeremy Bentham the publicist, devoted himself as a youth to the study of Naval Architecture, and at the age of 22, at the suggestion of Lord Howe, went to Russia with the view of further instructing 
himself in that science. Then he travelled to the Crimea, visited the naval establishments in the Baltic and the Black Sea, and thence went on to Siberia (penetrating to the frontiers of China) for the purpose of making himself acquainted with the mines, foundries, and other great industries of that country. Meanwhile he had gained the friendship of Prince Potemkin, who, impressed by his genius and ability, induced him to enter the service of the Empress Catherine II, who gave him a Lieutenant-Colonel's commission, without requiring him to pass through the subaltern grades of the army. In this capacity he was sent to the Crimea, where, amongst many other engineering feats, he built a flotilla of gun-boats, in command of which (under Prince Potemkin) he gained a signal victory over the whole Turkish fleet in the Black Sea. For this he received from the Empress the cross of St. George, conferring Knighthood, a sword of honour, and promotion to the rank of Colonel in command of a cavalry regiment in Siberia, which country he re-traversed from the Obi to the Amur, engaged chiefly in the construction of boats for the navigation of the Siberian rivers.

After the death of the Empress he returned to England, left the Russian service, and entered that of the Admiralty, by whom he was commissioned to return to Russia, and there superintend the building of some ships for the British Navy. Thither he went with his wife and family, including George, and remained, till the declaration of war with that country required his recall. Finally he rose to be Inspector of all our dockyards, in which capacity he introduced a multitude of improvements, including steam saw- and other mills, the replacement of water-casks in ships by iron tanks; and with Sir Isambard Mark Brunel, whom he brought over from the Continent, he constructed the eccentric machinery for turning elliptic blocks ${ }^{1}$.

G. Bentham's mother was the daughter of Dr. G. Fordyce, F.R.S., an eminent London physician, and lecturer on chemistry, author of various works on medicine and agri-

1 Sir Samuel Bentham's portrait hangs in Greenwich Hospital. 
culture. She was a woman of remarkable power of mind, who aided her father in his scientific labours, and her husband in preparing his voluminous official reports to the Admiralty. At the age of 80 she wrote a beautiful hand, and during the Crimean war, when considerably over 90 , she commenced a series of letters to the Times, urging the adoption of guns of a large calibre, and other improvements in war-material, the inventions of her late husband, whose Life she published in $\mathrm{I} 862$.

Not less influential on George Bentham's career was the teaching of his uncle Jeremy, who imbued him with that love for methodical and logical analysis which is so conspicuous in all his nephew's writings. As has been well remarked in this relation, "The same inherited aptitude and contemporary influences which produced a great publicist in Jeremy, yielded, by an almost accidental deflection, a great systematic botanist in his nephew' (Eulogium, p. 8).

Environments were as favourable to Bentham in his scientific career, as were the qualities of his progenitors. $\mathrm{He}$ was one of five children (three of them girls), all of them precocious. They were taught to read by words, not by syllables or letters, and the two brothers commenced learning Latin before they were five years old. In 1805 the whole family accompanied the father to Russia, where their education was entrusted to a talented Russian lady who could speak no English, whilst in Latin the boys were instructed by a Russian priest, of whom George in after life always spoke with great regard. Music, of which the latter became passionately fond, was not neglected, and it resulted in his becoming an accomplished pianist. Thus, having a remarkable facility for acquiring languages, Bentham could, at seven years old, converse fluently in English, French, German, and Russian, to which, by hard work, he added Swedish, during a detention of some weeks at Carlscrona on the voyage back to England. The said voyage proved a tempestuous and perilous one. Embarking at Revel in a Russian frigate, with a crew, few of whom had ever before seen the sea, they were tossed about in the Baltic 
for five weeks before arriving at Carlscrona; and there were as many equally stormy weeks in their passage thence in an ill-found merchantman to Harwich, where the family arrived in a half-starved condition, having been reduced to picking up stray scraps of biscuit in out-of-the-way corners of the cabins.

In England Sir Samuel Bentham took up his residence at Hampstead in the summer months, daily visiting his office at the Admiralty. In winter he resorted to a small house and property called Berry Lodge ${ }^{1}$, between Alverstoke and Gosport, which was in convenient proximity to Portsmouth Dockyard. The boys meanwhile pursued their studies under private tutors, a plan continued throughout the whole course of George's education. It was a life-long source of regret with George that he had never been sent to school or college, which may account for a shyness and reserve, attributed by those that did not know him to a want of sympathy.

In I8I2-I3, the invasion of Russia by Napoleon, and the burning of Moscow, naturally caused great excitement in the Bentham family. It led to the first appearance of George, then only I 3 , before the public; he, with his brother and sisters, contributing to the London Magazine a series of papers, gleaned from Russian sources, detailing the operations of the armies, and glorying in the reverses and final abdication of Napoleon.

After the proclamation of peace, Sir Samuel Bentham took his family to France, and resided successively at Tours, Saumur, and Paris. During this period, which extended from Napoleon's return from Russia to his final overthrow, young Bentham kept a full journal of all that passed, interspersed with anecdotes relating to the forced exile of Louis, the restoration of the Bourbons, the execution of Ney and

\footnotetext{
${ }^{1}$ It was from here that, while George was still in his teens, his father took him on a visit to Lady Spencer at Ryde, at whose house he met John Stuart Mill, a lad of six, dressed in a scarlet jacket buttoned over nankeen trousers, and considered to be a prodigy. Bentham has described him to me as having been wonderfully precocious, a Greek and Latin scholar, historian and logician, whom he heard discussing with Lady Spencer the relative merits of her ancestor, the Duke of Marlborough, and of Wellington, young Mill taking the part of the latter.
} 
Labedoyère, the condition of the city of Paris, and to Walter Savage Landor, who was intimate with the family. Even at this age he could take his part in the society of the leaders of the Paris Salons in literature and science, making the acquaintance of the Duc de Richelieu, Talleyrand, Dumas, Jean Baptiste Say, the aged Madame Andelau (daughter of Helvetius), and Alexander Humboldt. Of these the latter took an especial interest in him, encouraging him in the prosecution of a work he had begun on the data of physical geography, by advice and by procuring him introductions to libraries and to individuals who could aid him. Unfortunately this projected work was not continued.

In 18 I6 Sir Samuel Bentham organized at Paris a caravantour in France for himself and family. The caravan consisted of a two-horse coach fitted up as a sleeping-room, a one-horse spring van furnished with a library and piano, for himself and Mrs. Bentham, and another for his daughters and their governess. Thus equipped they travelled by day, visiting friends and places of interest, bivouacking by night in gipsy fashion in the gardens of friends, or in the precincts of the prefectures, to which he brought credentials from Paris. In this way he visited Orléans, Tours, Angoulême, Bordeaux, Toulouse, Montpellier, and finally Montauban, where the caravan having broken down, the tour was continued by ordinary conveyances to Carcassonne, Narbonne, Nîmes, Tarascon, Marseilles, Toulon, and Hyères.

The most interesting incident of this tour occurred at Angoulême, for there G. Bentham's attention was first directed to botany. His mother, who was fond of plants, and a friend of Aiton of Kew, had purchased a copy of De Candolle's just then issued 'Flore Française.' Young Bentham accidentally taking it up was interested in the analytical tables for determining the affinities and names of the plants described, which fitted in with the ideas he had derived from his uncle Jeremy's works, when constructing his own geographical tables. He at once went into the yard of the house, gathered the first plant he found, and after spending 
the morning in studying its structure, with the aid of the introductory chapter of the 'Flore,' succeeded in referring it to its order, genus, and species. The plant, Salvia pratensis, is not an easy one for a beginner. Encouraged by his success with it, he pursued the study of the native flora as a diversion, naming every plant he subsequently met with.

At Montauban, where his father had purchased a country house, which the family occupied for about two years, young George Bentham passed what he always regarded as the most enjoyable period of his life. He was entered as a student in a Protestant theological college, and followed with ardour the courses of mathematics, Hebrew, and comparative philo$\operatorname{logy}$, the latter a favourite study in after life. At home, during the holidays, he occupied his time with drawing plants, learning Spanish, and with music, society, and dancing, of which latter he was passionately fond. It was a favourite boast of his, that at Montauban he had danced at thirty-four balls between Twelfth-night and Mardi-gras, of which thirteen were consecutive, and lasted from 9 p.m. to 9 a.m. Here, too, his mind was first opened to scientific and exotic botany, to which he was led by the works of De Candolle, by the appearance of the 'Dictionnaire d'Histoire Naturelle,' and by a course of lectures under Benedict Prevost. This was followed by a devotion to ornithology, including shooting and stuffing birds, and that again by entomology, tabulating the phenomena of insect-life. Here, too, probably inspired by John Stuart Mill, who resided for some time with the family, his mind was turned to philosophy and the study of Lamarck's works, beginning with the 'Systeme analytique des Connaissances positives de l'homme,' only to give it up with disgust on reading that 'Dieu créa d'abord la matière,' followed by the statement that Nature was the second thing created, and that this produced everything else. More to the purpose was his translation into French of his uncle's Chrestomathia, which was a prelude to his becoming secretary to the great publicist at a later period.

From Montauban Sir Samuel Bentham moved to a large 
estate of 2,000 acres, which he had purchased, near Montpellier, and the management of which he made over to his now only son, the eldest having died some years previously. The estate consisted of farms and vineyards, to the improvement of which George devoted himself with alacrity and success. They became very profitable, and throughout the remainder of his life in England an excellent St. George Burgundy (the produce of the Restinalières estate), and a rare and luscious Lunel from a neighbouring vineyard, were familiar to the guests at his table. All his spare time was devoted to botanical excursions in the Cevennes and Pyrenees, and to making a French translation of his uncle's Essay on Nomenclature and Classification. Here, too, he wrote his first important work, 'Essai sur la Nomenclature et Classification des Arts et Sciences,' which was published in Paris, and which established his position as an acute analyzer, clear expositor, and cautious reasoner. Half a century after its appearance it was praised by Professor Stanley Jevons in his History of the Sciences.

In $1823 \mathrm{G}$. Bentham was sent to England for the purpose of obtaining agricultural implements and information as to improved methods of farming. On his arrival in London he was well received by his uncle, and introduced into the best literary and scientific society of the capital. He was invited to the breakfasts and receptions of Sir Joseph Banks, and studied in his library and herbarium, where he commenced a life-long friendship with their curator, Robert Brown, 'Botanicorum facile princeps.' There, and at the Horticultural and Linnean Societies, he met the élite of the naturalists of the day. From London he made a tour into Scotland, where he was hospitably entertained by the Professors of Botany in Edinburgh (Graham) and Glasgow (Hooker) ${ }^{1}$, and

\footnotetext{
${ }^{1}$ It was from this visit that Bentham was wont to date his permanent adherence to Botany. I, then six years old, remember him and the enthusiasm with which he received from my father a collection of Alpine Scotch plants, the first examples of the Northern European Flora he had ever seen. The intimate friendship between my father and Bentham, which lasted forty-two years, dates from this period.
} 
by Arnott, of Arlary, in Kinross-shire, who was subsequently Professor of Botany in Glasgow. With the latter he arranged to make an extended botanical excursion in the Pyrenees, which was carried out in 1824 , and which resulted in his first botanical work, 'Catalogue des Plantes Indigènes des Pyrénées et du Bas Languedoc, avec des notes et observations' (Paris, 1826). Another result of his Pyrenean exploration was the publication in the London Magazine for 1827 of two articles entitled 'Sketches of Manners in the South of France,' wherein, amongst much curious philological and other matter relating to the Roussillonais, Catalonians, and Languedociens, an account is given of a visit to the Lilliputian Republic of Andorra, its physical features, people, government, agriculture, and productions. These sketches are masterpieces of their kind.

In 1826 the Restinalières estate had to be abandoned, owing to provincial jealousy, which threw every obstacle in the way of improvements, and the Bentham family returned to England for good. Here a new, and as it proved, a very uncongenial career was opened to George. His uncle Jeremy, gratified by the translation of Chrestomathia, invited his nephew to be his aid in arranging his MSS. for the press, accompanying it with the assurance that he would provide for him at his death. This invitation was accepted, but not the offered provision, for he desired to follow an independent profession, and the result of many interviews was that he determined to enter Lincoln's Inn as a student of Law, whilst giving some morning hours to his uncle's work, dining with him twice a week, and writing for him after dinner, from 8 to I I p.m. In one capacity or another he acted as his uncle's secretary until $183^{2}$, when the death of the latter, in many of whose ideas he did not participate, released him from his irksome labour, without however fulfilling his just expectations of reward; for, owing to the many fruitless speculations of the great jurist, the sums squandered by his executors on the posthumous publications of his works, and some irregularities in his will, Bentham benefited chiefly by coming into pos- 
session of the house in Queen Square Place ${ }^{1}$. Here, after his marriage in 1833 to a daughter of the Rt. Hon. Sir Harford Brydges, Bart., formerly H. M. Envoy at the Court of the Shah of Persia, he resided until i 842. He had, however, been rendered independent through his father's death two years previously.

The amount and variety of mental work achieved by Bentham, during the years of bondage to his uncle, is very remarkable in many ways. Over and above his duties as his uncle's secretary, he had to arrange, often rewrite, and edit, his father's voluminous papers on the administration of the dockyards and other naval matters, and to study law. His legal studies were finally abandoned for logic and jurisprudence, but not till after he had published three notable papers; one on codification, on which subject he entirely disagreed with his uncle, but the paper attracted the attention of Brougham, Hume, and O'Connel. Another paper was on the laws affecting larceny, apropos of Sir Robert Peel's bill for the consolidation of the Criminal Law. Of this Peel thought so highly that he complimented its author, and informed him that it should be submitted to Sir John Richardson, to whom the bill was referred; a copy of it being shown by his uncle to Lord Brougham, the latter wrote a letter of eighteen pages of remarks upon it. The third was a pamphlet on the Law of Real Property. But his most considerable work of this period received scant attention from those most interested in its subject, and passed from its birth directly into an oblivion from which it was rescued only in later years, yet without word or sign from its author. This was his 'Outlines of a new system of Logic, with a critical examination of Dr. Whately's Elements of Logic,' published in 1827 . In it the Quantification of the Predicate ${ }^{2}$ was

1 It overlooked St. James's Park and the parade ground of Wellington Barracks, and its site is now approximately occupied by the 'Bentham wing' of the Queen Anne's Mansions. It had been in possession of the family for upwards of a century, having been purchased by Bentham's paternal grandfather.

${ }^{2}$ The following history of this episode in Bentham's career is, I think, too interesting and too important to be omitted in his obituary. It is taken from the 
xviii George Bentham, F.R.S.

first systematically applied in such wise that Professor Stanley Jevons declared it to be 'undoubtedly the most fruitful discovery made in abstract logical science since the time of Aristotle.' Meanwhile Bentham had been called to the Bar by Lincoln's Inn, but his career as a barrister was the briefest. As counsel in a case he broke down in court through nervousness, and thenceforth wisely abandoned the practice of the profession.

In botany Bentham was more at home than in the Lawcourts. In 1828 his herbarium arrived from France, and in the same year he was elected a Fellow of the Linnean

Memorial by Protessor Gray: "Before sixty copies of the work had been sold, the publishers became bankrupt, and the whole impression of this work of a young and unknown author was sold for waste paper. One of the extant copies, however, came into the hands of the distinguished philosopher, Sir W. Hamilton, to whom the discovery of the quantification of the predicate was credited, and who, in claiming it, brought an acrimonious charge of plagiarism against Professor De Morgan upon this subject : yet this very book of Mr. Bentham's is one of the ten placed by the title at the head of Sir William Hamilton's article on Logic in the Edinburgh Review for April, 1833 , and is once or twice referred to in that article; and a dozen years later, in the course of the controversy with De Morgan, Sir William alluded to the article, as containing the germs of his discovery. We may imagine the avidity with which De Morgan, injuriously attacked, would have seized upon Mr. Bentham's book if he had known of it. It is not so easy to understand how Mr. Bentham, although then absorbed in botanical researches, could have overlooked the controversy in the Athenaeum, or how, if he knew of it, he could have kept silence. It was only at the close of 1850 that Mr. Warlow sent from the coast of Wales a letter to the Athenaeum, in which he refers to Bentham's book as one that had long before anticipated this interesting discovery. Although Hamilton himself never offered an explanation of his now unpleasant position (for the note obliquely referring to the matter in the second edition of his Discussions is not an explanation), Mr. Bain did (in the Athenaeum for Feb. I, I85I); he immediately endeavoured to discredit the importance of Bentham's work, and again in 1873 (Contemporary Review, Vol. xxi) in reply to Herbert Spencer's reclamation of Bentham's discovery. To this Stanley Jevons made reply in the same volume (pp. 82I-824); and later in his Principles of Science (ii. p. $3^{87}$ ) this competent and impartial judge, in speaking of the connexion of Bentham's work "with the great discovery of the Quantification of the Predicate " adds, "I must continue to hold that the principle of quantification is explicitly stated by Mr. Bentham; and it must be regarded as a remarkable fact in the history of logic, that Hamilton, while vindicating in $\mathrm{I}_{47}$ his own claims to originality and priority as against the scheme of De Morgan, should have overlooked the much earlier and more closely related discoveries of Bentham. It must be that Hamilton reviewed Bentham's book without reading it through, or that its ideas did not at the time leave any conscious impression upon the reviewer's mind, yet may have fructified afterwards." 
Society, the meetings of which, the anniversary dinners, and those of its club, he punctually attended. Soon after this Robert Brown proposed his name for election by the Royal Society, but withdrew it before the day fixed for election, to mark the dissatisfaction on the part of the scientific Fellows with the management of the Society, when a Royal Duke was made President. It was not until I 862 that he was again proposed and elected.

In 1829 , at the joint solicitation of his friend Mr. Joseph Sabine, the Hon. Secretary, and Dr. Lindley, Assistant Secretary, who were at issue as to the management of the Horticultural Society, he accepted the honorary secretaryship himself, and held it until 1840 . On his entering office the Society was in a perilous position from debt and dissensions, from which, with Lindley's active co-operation, he rescued it. It was during his term of office that the celebrated Chiswick Horticultural fêtes were inaugurated, which gave a new life to the science. At the first of these, held on April 3, 1832, seventeen hundred persons were present. It was during the same period that so many of our most popular garden-plants were introduced, especially from California, through collectors sent out by the Society (Douglas, Hartweg, and others). These plants were named, and many novelties amongst them described, by Bentham in the Society's publications; to which he also contributed a translation of Targioni-Tozetti's 'Historical Notes on Cultivated Plants,' in which he added much valuable matter to the author's work. At about this time Dr. Wallich returned from India with his enormous collection of Himalayan, Burmese, and Indian plants, destined to be named and distributed to the principal herbaria in Europe by the Honourable East India Company. In furtherance of this great work Bentham offered his aid to Dr. Wallich, with whom he co-operated zealously for several successive years. Over and above his gratuitous labours as an assistant, he undertook the naming and distributing of the orders Euphorbiaceae and Gramineae, lithographing the tickets of the latter with his own hand. This marks an epoch in 
his career, for it was his introduction to a tropical flora (which he was never privileged to see), and afforded the chief materials for his first work on exotic plants, the 'Scrophularineae Indicae, published in 1835 . This was followed, in 1836 , by the completion of his great work, 'Labiatarum genera et species, or a description of the genera and species of the order Labiatae, with their general history, characters, affinities, and geographical distribution,' which gave him a position in the very foremost ranks of taxonomic botanists ${ }^{1}$. It was followed, in I 837 , by his enumeration of plants collected in the Swan River district by Baron Hugel (Vienna, 1837), which is remarkable as showing the ease and rapidity with which he mastered a Flora totally different from those he had previously studied.

From the summer of 1836 till the early part of 1837 he resided with his wife in Germany, visiting the principal Botanic Gardens and Herbaria, especially engaged in studying the order Leguminosae; his account of these and of the botanists whom he met was communicated in letters to Sir W. Hooker, and published (anonymously) in the Companion to the Botanical Magazine (Vol. ii) and Journal of Botany (Vol. i). They are very interesting as contributions to the History of Botany in the first third of the century. During the winter at Vienna he published his masterly 'Commentationes de Leguminosarum generibus' in the 'Annalen des Wiener Museums' (Vol. ii).

In $1846-7$ he undertook, accompanied by his wife, an extended tour in Europe. Commencing with Hamburg, they visited Copenhagen, Stockholm, St. Petersburg, Moscow, Odessa, Constantinople, Trieste, Bologna, Florence, Leghorn, Naples, Rome, Palermo, and Geneva. What he saw in these towns and their environs of botanical, horticultural, and other

\footnotetext{
1 To give some idea of the thoroughness of Bentham's methods, it is well to state, that in prosecution of this work he visited the following herbaria:-in I8 30 Hamburg and Berlin; in 183 1 Paris, Geneva, Avignon, and Montpellier ; in 1832 Hamburg again, Copenhagen, Leipzig, Dresden, Prague, Vienna, and Munich ; in 1833 Paris and Montpellier again; and in 1834 Bonn, Frankfort, Geneva again, Pavia and Turin (Labiat. Gen. and S., Pref. p. v).
} 
interest was communicated in thirty-one anonymous letters to the Gardener's Chronicle (Vols. 1 846-7). Like those mentioned above from Germany, they are of great value as contributions to the history of botany and horticulture during the period in which they were written.

With the view of providing better accommodation for his library and herbarium, and devoting himself exclusively to science, Bentham removed in $I 842$ to Pontrilas, an Elizabethan manor house belonging to his brother-in-law, Colonel Scudamore. Here his chief occupation was providing material for the continuation of Auguste De Candolle's 'Prodromus systematis naturalis Regni Vegetabilis,' which had been undertaken by his (Bentham's) intimate friend, Alphonse De Candolle. In this work he contributed the Ericeae, Polemoniaceae, Scrophularineae, Eriogoneae, and a greatly enlarged revision of the Labiatae, amounting in all to over 4,730 species. During the same interval he published the Botany of the Voyage of the Sulphur in the Malayan seas and Pacific ocean, a quarto work with 60 plates.

Whilst resident at Pontrilas he also did his duty as Justice of the Peace for the county of Hereford with punctuality and efficiency.

In 1854 , finding that the cost of keeping up his library and herbarium threatened to exceed his income, he determined to offer these to the Government, with the stipulation that they should form part of the establishment of $\mathrm{Kew}^{1}$, he himself abandoning botany, and removing from Pontrilas to London. This munificent offer was of course gladly accepted by the Government, and the materials were placed in what is now called the Herbarium building of Kew, to be subsequently amalgamated with the richer collections of books and plants

1 Where there were at that time no other library or herbarium than the private ones of Sir W. Hooker, which he had been permitted to deposit in a house previously in the occupation of one of the Royal Family. The said house had, at the advice of Sir Joseph Banks, been purchased by George III for the very purpose which it now serves, and one room was actually shelved for the books. On the death of the king and his scientific counsellor, in the same year, the house was otherwise appropriated. 
of Sir W. Hooker. On the other hand, the idea of Bentham's giving up botany was a shock to his scientific friends at home and abroad, and especially to the oldest and most intimate of them, Sir W. Hooker, who begged him to reconsider his intention, combated his own modest estimate of himself as a mere amateur systematist, and pointed out to him that a residence in London offered the means of study at Kew, where a room, containing his own herbarium, should be devoted to his use, and where he would be in proximity to the garden, museum, and collections already at Kew. Fortunately Sir W. Hooker's counsels, backed by those of other friends, especially Dr. Lindley, prevailed. In I 855 he took up his residence in London, for the first few years in Victoria Street, Westminster, and for the remainder of his life in 25 Wilton Place, between Hyde Park and Belgrave Square. From London he went to Kew daily (a few weeks of autumn holidays excepted) for five days a week, with perfect regularity, arriving at Io a.m. and leaving at 4 p.m., devoting the evenings to writing out the notes of his day's work, and never breaking the long fast between breakfast at 8 or 8.30 and dinner at 7.30 or 8 . "With such methodical habits, with freedom from professional or administrative functions, which consume the time of most botanists, with steady devotion to his chosen work, and with nearly all authentic material and needful appliances at hand or within reach, it is not surprising that he should have undertaken and have so well accomplished such a vast amount of work, and he has the crowning merit and happy fortune of having completed all that he undertook' (A. Gray, Memorial).

No sooner was Bentham settled within reach of Kew than he was induced by Sir W. Hooker to inaugurate a series of Colonial Floras, which had been planned by the former, and of which the first is that of Hong-Kong ${ }^{1}$. It was followed by the 'Flora Australiensis,' in seven volumes, which is the first flora of any large continental area that has ever been

1 The 'Flora Hong-Kongensis,' published in I86I, one vol. 8vo, pp. 455, contains $\mathrm{I}, 003$ species. 
finished. It was commenced in I86I, and was concluded in 1870 ; it comprises about 7,000 species. He was aided in it by valuable notes and preliminary studies supplied by Baron Mueller, but every description, generic and specific, was strictly his own. As has been well said, 'it is a work which would alone found a reputation.'

But Bentham's magnum opus is unquestionably the 'Genera Plantarum 1', issued under the joint authorship of himself and the contributor of this memoir to the Annals; but which, whether for the overwhelming share of the work which Bentham undertook, or for the aid he gave his partner in certain Orders elaborated by the latter, may justly be regarded as on the whole the product of one botanist. In the planning and execution of the work only two points were contested between us, whether his or my name should take precedence on the title-page, and whether in the headings of the pages the author's name should be given with that of the Order described. On the first point my opinion prevailed, his on the second.

The only other separate work published by Bentham during this period was an Illustrated Handbook of the British Flora, for the use of beginners and amateurs, including a series of wood-engravings, with dissections, by W. H. Fitch, F.L.S. The first edition of the Handbook appeared in $185^{8}$, and has been succeeded by five others. This work, on its appearance, was criticized on the false assumption that its author had no knowledge of plants in the field, supported by the fact that he took a much wider view of the variations under which species present themselves in nature, than do authors who have that knowledge. It was unknown to, or forgotten by,

\footnotetext{
1 Genera Plantarum ad Exemplaria, imprimis in Herbariis Kewensibus servata, definita, auctoribus G. Bentham et J. D. Hooker, I862-I883. The last article which Bentham wrote was a communication to the Linnean Society (Proc. xx, I 883, p. 304): On the joint and separate work of the authors of Bentham and Hooker's 'Genera Plantarum'; where a full account is given of the part each author took. It may be mentioned that with the view of reducing the price of the work to the public as far as possible, the expense of production was defrayed by the authors, Mr. Bentham guaranteeing that his fellow anthor should not lose.
} 
his critics, that he had for half-a-century observed, collected, and preserved most of the species of the British Flora over a great part of Continental Europe, as well as in the British Isles, that his views were founded on wide experience, and that the results of them in terms of genera and species were drawn up from examination, in almost every case, of living examples. The Handbook was a great favourite of Mr. Darwin, whose admiration of the masterly way in which the author dealt with the main features of the British Flora, drew from him the exclamation, 'Good Heavens! to think of British botanists turning up their noses and saying that he knows nothing of British plants ${ }^{1}$ '

Bentham's labours at Kew on the above three works were interrupted by several serious demands on his time and energies, his response to which places in a striking light his disinterested devotion to the progress of science. Of these the most important was his acceptance of the Presidency of the Linnean Society. This he accepted in 1863 , and threw himself into the duties of the office, which he discharged for eleven years, with energy, wisdom, and singleness of purpose; and, it should be recorded, with no small expenditure of his means. It made no difference in respect of the time devoted to his work at Kew; for the one day of the week which he had reserved for his own affairs was thereafter devoted wholly, or in part, together with much of his evening hours, to the Society's affairs. During the years in which he held office he took the chair at the evening and council meetings, with all but unbroken punctuality. On the transference of the Society's library, collections, and portraits, to the apartments in Burlington House provided by the Government, he personally superintended the arrangements, classifying the books, and literally with his own hands placing them on the book-shelves; and he himself indexed

${ }^{1}$ Life and Letters, Vol. ii, p. 363 . It must not be supposed that Bentham disparaged the labours of those who aimed at what he considered the multiplication of species. No naturalist was more appreciative of accurate work in this department of botany, and of its value. 
the first ten volumes of the Transactions. He constituted himself the editor of most of the botanical papers published in the Transactions and Journal, in some cases earning the gratitude of the authors by rearranging their matter (with their approval), and himself rewriting their papers. His annual presidential addresses were remarkable for their wide range of knowledge, and those who knew him only as a systematist and descriptive botanist recognized with surprise the power of analysis and sound judgment which he displayed in these addresses, wherein he discussed evolution in all its bearings, the writings of Haeckel, geographical distribution, the prospects of fossil botany, deep sea life, abiogenesis, methods of biological study, the histories and labours of the principal Natural History Societies, and periodicals of every civilized country on the globe.

In respect of evolution, perhaps the most important of his addresses is that of 1863 , dealing with discussions on the Origin of Species. Alluding to his own subsequent tardy adoption of the theory of the Survival of the Fittest, he says: 'I scarcely think that due allowance is made for those who, like myself, through a long course of study of the phenomena of organic life, had been led more or less to believe in the immutability of species within certain limits, and have now felt their theories rudely shaken by the new light opened on the field by Mr. Darwin, but who cannot surrender at discretion so long as many important outworks remained contestable.' In correspondence with Mr. Darwin on some of these outworks, the latter in a letter dated June 19,1863 , alluding to the effect of the address as a whole, wrote $^{1}$ : 'I verily believe that your address, written as it is, will do more to shake the unshaken and bring in those leaning to our side than anything written in favour of transmutation.' It is interesting to find in later addresses, a frank acceptance of evolution, in such passages as those in which he recognizes 'the coexistence of indefinite permanency, and of gradual or rapid change in different races in the same

1. Life and Letters, Vol. iii, p. 26. 
area, and under the same physical conditions'; and, 'we must now test our species as well as genera or other groups, by such evidence as we can collect of affinity derived from consanguinity.' In short, as with Lyell in the later editions of his famous Principles of Geology, when dealing with the history of life on the globe, Bentham had to underpin his edifices, and replace their old foundations with new. Happily in the cases of both philosophers, this was effected without injury to the superstructures.

This brief notice of Bentham's final adhesion to Darwin's views may be supplemented by the following interesting extract from a letter he wrote to Francis Darwin ${ }^{1}$, May 2, I882 (two years before his death). It says :- ' I have always been throughout one of his (Darwin's) most sincere admirers, and fully adopted his theories and conclusions, notwithstanding the severe pain and disappointment they at first occasioned me. On the day that his celebrated paper was read at the Linnean Society, July I, I858, a long paper of mine had been chosen for reading, in which, in commenting on the British Flora, I had collected a number of observations and facts illustrating what I then believed to be a fixity of species, however difficult it might be to assign their limits, and showing a tendency of abnormal forms produced by cultivation or otherwise to withdraw within their original limits when left to themselves. Most fortunately my paper had to give way to Mr. Darwin's, and when once that was read, I felt bound to defer mine for reconsideration; I began to entertain doubts on the subject; and on the appearance of the Origin of Species I was forced, however reluctantly, to give up my long cherished convictions, the results of much labour and study, and I cancelled all that part of my paper which urged original fixity.' This paper of Bentham's was never published.

Of the many laborious tasks undertaken and gratuitously performed by Bentham, chiefly at Kew, the following deserve especial notice. First and greatest was the equipment of 
the University of Cambridge with an authentically named consulting herbarium. This consisted for the most part of that of his friend, Dr. C. Leman, F.L.S., a zealous collector, especially by purchase, which he was disposed to leave by will to Bentham. The latter, on the other hand, urged its being left to Cambridge, of which Dr. Leman was a graduate in medicine. It was finally arranged between them, that on his friend's death the collections should be sent to Bentham, who should select from them any specimens which he might want for his own herbarium, whilst the remainder (the much larger portion), augmented by duplicates from Bentham's herbarium, should go to Cambridge. Aided by a small grant from the University for the purchase of paper, for the expenses of mounting and poisoning the specimens, and for other contingencies, Bentham classified, named, had fastened down and enclosed in genus-covers, a consulting herbarium of 30,000 species. This great labour occupied more or less of ten years of his life. Other gratuitous tasks were the ticketing, and dividing into sets for sale, of the collections of Robert and Richard Schomburgk in Guiana and Brazil, and of Hartweg ${ }^{1}$ in British Columbia, California, and Mexico. A still greater service to science was his undertaking the distribution and sale of the magnificent collections of the distinguished traveller Richard Spruce in the Amazon region and Peru. These, amounting in all to 6,500 numbers, were sent to him as collected, to be arranged, named, and divided into twenty to thirty sets, for which he obtained subscribers in the principal public and private museums in Europe and America. He further collected the money due by the subscribers, transmitting it to Spruce, who depended on it for the prosecution of his thirteen years of exploration, thus saving to all parties the expenses of agency and commission.

Bentham's last work was the 'Genera Plantarum,' of

${ }^{1}$ Of Hartweg's plants he published a catalogue, with descriptions of new genera and species under the title of 'Plantae Hartwegianae.' It enumerates about 2,000 species. 
which the first part appeared in July $\mathbf{1} 862$, the concluding in April 1883. The closing years of his life are feelingly described by $\mathrm{Mr}$. Thiselton-Dyer in his Eulogium, in the following words:-'In the latter years of his life Bentham was not less imbued with affection for his task, though the sense of the precariousness of life chiefly affected him with anxiety as to its completion. The flame of his intellectual powers never burnt more brightly, too brightly perhaps for a frame which slowly but perceptibly enfeebled. During the last years of what was a supreme effort, it was impossible not to feel a degree of awe for the intense devotion with which he pursued, without intermission, his self-imposed labour. Towards the last it appeared to one that by mere effort of will he actually sustained his bodily vitality. When the last revise of the last sheet ${ }^{1}$ was returned to the printer, the stimulus was withdrawn. Nature, so long indulgent, would no longer be withstood. He came once or twice again to Kew, but found no task that he could settle to. At home he commenced a brief autobiography. The pen ${ }^{2}$ with which he had written his two greatest works broke in his hand in the middle of a page. He accepted the omen, laid aside the unfinished manuscript, and patiently awaited the not distant end.'

I cannot better conclude this attempt to convey an adequate idea of the value and amount of Bentham's labours, than by citing a passage from his intimate friend's, Dr. Asa Gray's, Memorial, premising that the latter botanist most nearly approached him of all his scientific contemporaries in the qualities he alludes to and the range of his work. He writes:- ' It will have been seen that Mr. Bentham confined himself to the Phanerogams, to morphological,

${ }_{1}$ This was the general index, which, as those of each successive part, he made himself, so scrupulous was he in his efforts to avoid error, even in so mechanical an operation.

2 This was one of Mordan's gold pens, which have I think iridium nibs. It ' wrote' not only the seven volumes of the 'Flora Australiensis,' and the three of the 'Genera Plantarum,' but a vast number of botanical papers and letters. The pen -holder is preserved at the Herbarium, Kew. 
taxonomical, and descriptive work, not paying attention to the Cryptogams below the Ferns, nor to vegetable anatomy, physiology or palaeontology. He was what may be called a botanist of the old school. Up to middle age, and beyond, he used rather to regard himself as an amateur, pursuing botany as an intellectual exercise. "There are diversities of gifts," perhaps no professional naturalist made more of his, certainly no one ever laboured more diligently, nor indeed more successfully over so wide a field, within these chosen lines. For extent and variety of good work accomplished, for an intuitive sense of method, for lucidity and accuracy, and for insight, George Bentham may fairly be compared with Linnaeus, De Candolle, and Robert Brown.' This is a just tribute to his memory, to which I would add my own, that method, grasp of subject, and thoroughness, were his watchwords.

It remains to allude to his personal characteristics. He was tall, of spare habit, with a slight stoop in his gait; his features were strongly marked, his complexion rather dark, his hair black and eyebrows bushy. The likeness ${ }^{1}$ accompanying this memoir is an excellent one. In dieting himself, he was extraordinarily abstemious, taking but two meals a day, and those most sparing. Though shy and reserved in manner, he was a most amiable, warmhearted man, the kindest of help-mates, and the most disinterested of friends. As a companion or guest he was charming, high bred, and courteous, communicative of stores of anecdotes and reminiscences of the events he had witnessed, the interesting people he had known, and the places he had seen all over Europe. To which must be added his musical gift, which was at the service of whoever asked for it. To recognitions and honours he was indifferent. $\mathrm{He}$ gratefully received the Royal Medal from the Royal Society, awarded in I 859, and the Clarke Medal of the Royal Society

\footnotetext{
${ }^{1}$ It is a reproduction of the portrait, painted in 1870 by Lowes Dickinson, in the possession of the Linnean Society of London, by whose kind permission it has been here reproduced.
} 
of New South Wales in 1878 ; but it was with great difficulty that he was prevailed upon to receive the Companionship of St. Michael and St. George, conferred on him by Her Majesty. He was a correspondent of the Institute of France, and member of the Academies of Science of Berlin, St. Petersburg, and America, and of many other scientific Societies that cultivate Natural History.

Bentham died of old age at his house in Wilton Place, December IO, I884, shortly after his eighty-fourth birthday, retaining his faculties to the last. His wife predeceased him by four years; he never had any family. The bulk of his modest fortune went to his only relative, a great-niece residing in France, after liberal bequests to the Linnean Society and the scientific relief fund of the Royal Society, and of a considerable sum under trust to be expended in the interest of the herbarium at Kew, especially in continuing the publication of Hooker's Icones Plantarum, a work in which he took a great interest, having indeed provided the plates and letter-press of several volumes at his own expense.

J. D. HOOKER. 


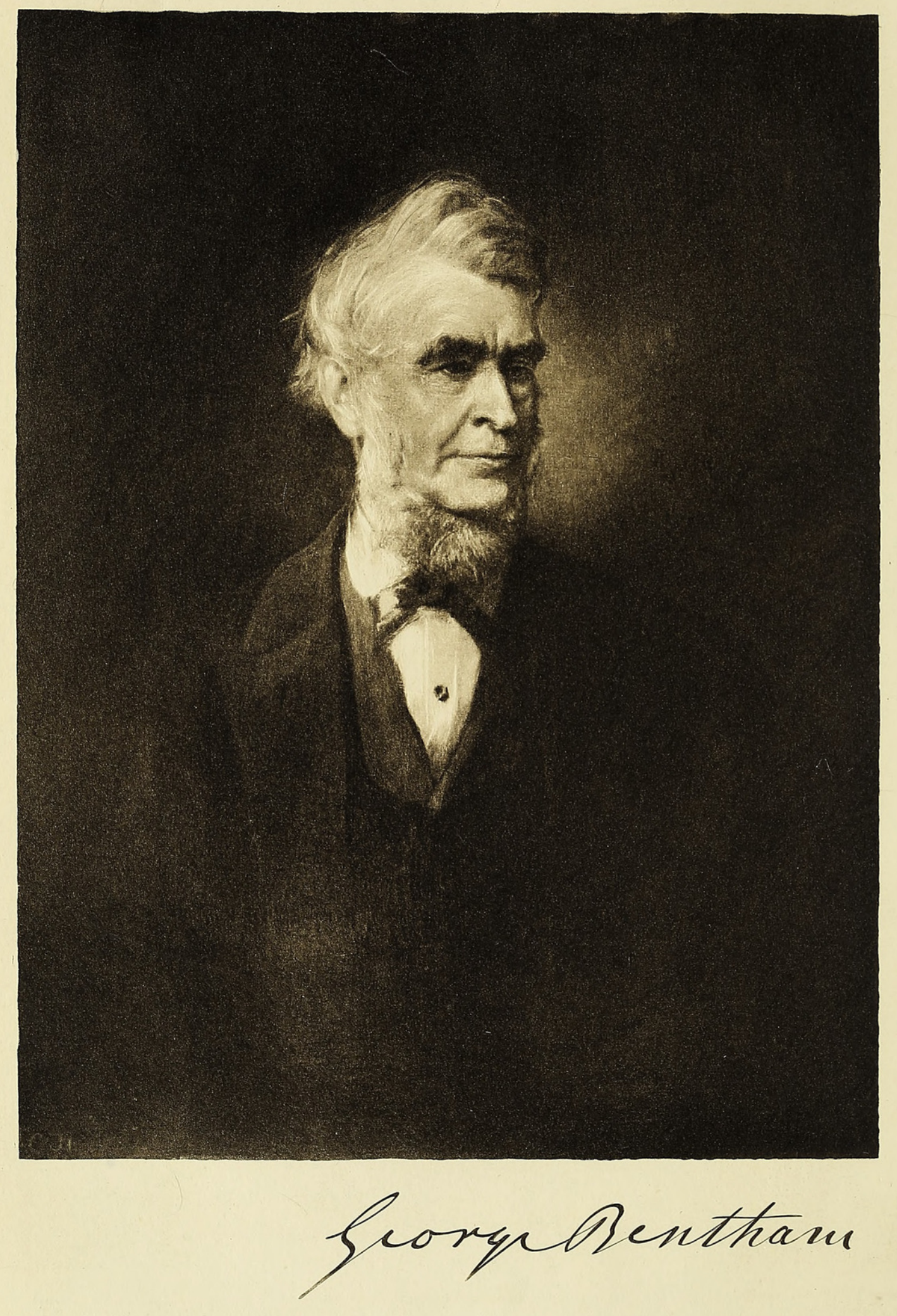




\section{$2 \mathrm{BHL}$ Biodiversity Heritage Library}

Hooker, Joseph Dalton. 1898. "George Bentham, F.R.S. [Obituary]." Annals of botany 12, ix-xxx. https://doi.org/10.1093/oxfordjournals.aob.a088677.

View This Item Online: https://www.biodiversitylibrary.org/item/233102

DOI: https://doi.org/10.1093/oxfordjournals.aob.a088677

Permalink: https://www.biodiversitylibrary.org/partpdf/318489

\section{Holding Institution}

Smithsonian Libraries

\section{Sponsored by}

Biodiversity Heritage Library

\section{Copyright \& Reuse}

Copyright Status: Not in copyright. The BHL knows of no copyright restrictions on this item.

This document was created from content at the Biodiversity Heritage Library, the world's largest open access digital library for biodiversity literature and archives. Visit BHL at https://www.biodiversitylibrary.org. 